Jurnal ABDINUS : Jurnal Pengabdian Nusantara, 3 (1), 2019, 1-10

Available online at: http://ojs.unpkediri.ac.id/index.php/PPM

DOI: https://doi.org/10.29407/ja.v3i1.12625

\title{
Pendampingan Pembuatan Key Performance Indicator Sebagai Perencanaan Program Kerja Tahunan dan Multi Tahun Berbasis Balance Score Card Pada Unit Pelaksana Teknis Daerah Balai Latihan Kerja (UPTD BLK) Disnakertransos Kabupaten Tulungagung
}

\author{
Bayu Cahyoadi ${ }^{1}$, Andreas Andre Djatmiko ${ }^{2}$ \\ ${ }^{1}$ cahyoadi.bayu@stkippgritulungagung.ac.id \\ ${ }^{1}$ Prodi Pendidikan Ekonomi \\ ${ }^{2}$ Prodi Pendidikan Pancasila dan Kewarganegaraan \\ ${ }^{1,2}$ STKIP PGRI Tulungagung
}

Received: 1312 2018. Revised: 1904 2019. Accepted: 28082019

\begin{abstract}
Regional Technical Implementation Units (UPTD) Work Training Centers (BLK) and Regional Revenue Bodies (Bapenda) Disnakertrans Tulungagung Regency is a newly established public organization. As a new public sector, an institution should have maturity in the fields of management and organization that are reflected in measurable work plans, regulations, clear governance, standard operation procedures, and guarantees of quality quality of institutions and graduates who must always be evaluated with appropriate instruments. This program takes one of the above BCS perspectives, namely the internal business perspective; from the perspective of a strategy based on Human Resources (HR). The making of the BSC will be based on the details of the governance that has been determined by the laws and regulations related to the two UPTDs which are then determined by the indicators of the implementation of the work program based on the capacity of the HR they have. The making of the work program indicator is based on the key performance indicator (KPI) theory. The aim of the program and the benefits of this program is to become one of the proofs of good cooperation between the institutions of STKIP PGRI Tulungagung and the Regency Government of Tulungagung Regency especially at the UPTD BLK and Bapenda Disnakertrans; to donate lecturers' knowledge to the public; and to improve the quality of management of government / public sector management in the Tulungagung Regency area. While the benefits generated from this program are the creation of good cooperation between higher education institutions and the government; the creation of management management that refers to relevant scientific theory; the creation of high management management standards in government institutions, especially the BLK UPTD and the Bapenda Disnakertrans Tulungagung district.
\end{abstract}

Keywords: key performance indicator, work program planning, balance score card

Abstrak: Unit Pelaksana Teknis Daerah (UPTD) Balai Latihan Kerja (BLK) dan Badan Pendapatan Daerah (Bapenda) Disnakertrans Kabupaten Tulungagung merupakan organisasi publik yang baru saja didirikan. Sebagai sektor publik baru selayaknya sebuah instansi mempunyai kematangan 
dalam bidang manajemen dan organisasi yang ditungkan dalam perencanaan kerja yang terukur, peraturan, tata kelola, standar operation procedure yang jelas, serta jaminan akan kualitas mutu lembaga dan lulusan yang senantiasa harus dievaluasi dengan instrument yang layak. Program ini mengambil salah satu perspektif BCS di atas yaitu perspektif bisnis internal; dari sudut pandang strategi yang berbasis pada Sumber Daya Manusia (SDM). Pembuatan BSC akan didasarkan pada rincian tata kelola yang telah ditetapkan peraturan perundangan yang terkait dengan kedua UPTD tersebut yang kemudian ditentukan indikator pelaksanaan program kerja berdasarkan kapasitas SDM yang dimiliki. Pembuatan indikator program kerja ini dilakukan berdasarkan acuan teori Key performance Indicator (KPI). Tujuan program dan manfaat program ini adalah Untuk dijadikan salah satu bukti kerjasama yang baik pihak institusi STKIP PGRI Tulungagung dengan pihak Pemkab Kabupaten Tulungagung khususnya pada UPTD BLK dan Bapenda Disnakertrans; untuk menyumbangkan khasanah pengetahuan dosen kepada masyarakat; dan untuk untuk meningkatkan mutu pengelolaan manajemen pemerintahan/sektor publik di wilayah Kabupaten Tulungagung. Sedangkan manfaat yang dihasilkan dari program ini adalah terciptanya kerjasama yang baik antar institusi perguruan tinggi dan pemerintah; terciptanya pengelolaan manajemen yang mengacu pada teori ilmiah yang relevan; terciptanya standar pengelolaan manajemen yang tinggi pada institusi pemerintah khususnya UPTD BLK dan Bapenda Disnakertrans kabupaten Tulungagung.

Kata kunci: key performance indicator, perencanaan program kerja, balance score card

\section{ANALISIS SITUASI}

Peraturan pemerintah yang menyebutkan bahwa masing-masing Pemkab di Wilayah Jawa Timur harus memiliki Balai Latihan Kerja telah diwujudkan oleh Pemkab Tulungagung dibawah Dinas Sosial Tenaga Kerja dan Transmigrasi (Dinsosnakertrans) melalui pembentukan Unit Pelaksana Teknis Daerah (UPTD) alai Latihan Kerja. Unit tersebut merupakan unit yang baru sebagai sasrana mencetak tenaga kerja yang handal, yang berkompetensi tinggi dan mampu memenuhi keinginan resapan pasar tenaga kerja dan kewirausahaan.

Balai Latihan Kerja Disnakertrans (BLKD) Kabupaten Tulungagung dan Badan Pendapatan Daerah (Bapenda) merupakan organisasi publik yang baru saja didirikan. Sebagai sektor publik baru selayaknya sebuah instansi mempunyai kematangan dalam bidang manajemen dan organisasi yang ditungkan dalam perencanaan kerja yang terukur, peraturan, tata kelola, standar operation procedure yang jelas, serta jaminan akan kualitas mutu lembaga dan lulusan yang senantiasa harus dievaluasi dengan instrument yang layak. 


\section{Jurnal ABDINUS : Jurnal Pengabdian Nusantara, 3 (1), 2019, 1-10 \\ Bayu Cahyoadi, Andreas Andre Djatmiko}

Sebagai sektor publik baru dan melayani mayarakat dalam berbagai bidang pekerjaan, tentu saja BLKD dan Bapenda selayaknya memiliki sebuah tata kelola manajemen yang mampu dicontoh oleh para peserta didik. Peserta didik yang lulus yang bekerja dan/atau memiliki usaha sendiri tidak menutup kemungkinan untuk kembali berkonsultasi mengenai bidang pekerjaan dan atau bisnis yang dibidangi. Selain itu dengan pengelolaan manajemen yang baik peserta didik akan merasa dilatih dan ditangani oleh sebuah sektor publik yang handal yang mampu membawa arah masa depan yang lebih baik. "Profesional" merupakan salah satu sebutan terbaik yang diharapkan dapat diberikan para peserta didik yang ditangani oleh BLKD.

Sebagai titik awal perwujudan model manajemen yang berbasis strategi, dibutuhkan suatu pengetahuan khusus kepada para pimpinan dan staf BLKD serta Bapenda untuk bekerja berdasarkan program kerja yang matang. Satu sisi pimpinan melakukan perencanaan yang jelas tentang tujuan yang akan dicapai untuk masa depan sedangkan staf berusaha mengartikulasikan program dan target dari atasan untuk dilaksanakan sesuai dengan prosedur pelaksanaan yang berlaku.

Balance Score Card (BSC) adalah perencanaan dan manajemen sistem strategis yang digunakan secara luas dalam bisnis dan industri, pemerintah, dan organisasi nirlaba di seluruh dunia untuk menyelaraskan kegiatan usaha dengan visi dan strategi organisasi, meningkatkan komunikasi internal dan eksternal, dan memantau kinerja organisasi terhadap tujuan strategis (Umayal Karpagam and Suganthi 2012).

BSC menjadi lebih formal pada tahun 1992 ketika Kaplan dan Norton membingkai hal tersebut ke dalam empat perspektif pengukuran yang berbeda (Schobel 2012); yang meliputi:

1. Perspektif pelanggan

2. Perspektif finansial

3. Perspektif bisnis internal

4. Pembelajaran dan pertumbuhan

Program ini mengambil salah satu perspektif BCS di atas yaitu perspektif bisnis internal; dari sudut pandang strategi yang berbasis pada Sumber Daya Manusia (SDM). Pembuatan BSC akan didasarkan pada rincian tata kelola yang telah ditetapkan peraturan perundangan yang terkait dengan UPTD BLK dan Bapenda Disnakertrans yang kemudian ditentukan indikator pelaksanaan program kerja berdasarkan kapasitas SDM yang dimiliki.

Pembuatan indikator program kerja ini dilakukan berdasarkan acuan teori Key performance Indicator (KPI). Faktor kunci keberhasilan dan indikator kinerja utama (KPI) 
yang terkait dengan empat bidang keuangan, pelanggan, proses internal, serta produktif dan berkembang diidentifikasi menurut ketersediaan peta strategis dan rantai nilai (Ahmadi et al. 2012). Pada program ini peta strategis ditentukan berdasarkan tata kelola yang telah didapatkan karena merupakan langkah awal menentukan strategi pada publik sektor yang baru. Harapan tertinggi dari kegiatan ini adalah adanya pemetaan strategi yang lebih baik dari dalam diri institusi UPTD BLK Disnakertrans; berdasarkan pencapaian kinerja dari program kerja yang telah dibuat.

Program ini akan memberikan wawasan pentingnya BSC untuk perusahaan sektor publik; untuk dapat digunakan sebagai salah satu perencanaan, pelaksanaan, dan pengendalian program kerja yang kemudian dapat dievaluasi dan diperbaiki seiring perkembangan isu strategis dan tujuan di masa yang akan datang. Program ini merupakan salah satu awal dari rangkaian kegiatan pengabdian masyarakat dalam mewujudkan penataan manajemen bermutu tinggi pada sektor publik yang berbasis manajemen strategik, dengan roadmap pengabdian masyarakat yang akan dijabarkan pada Gambar 1.1 sebagai berikut.
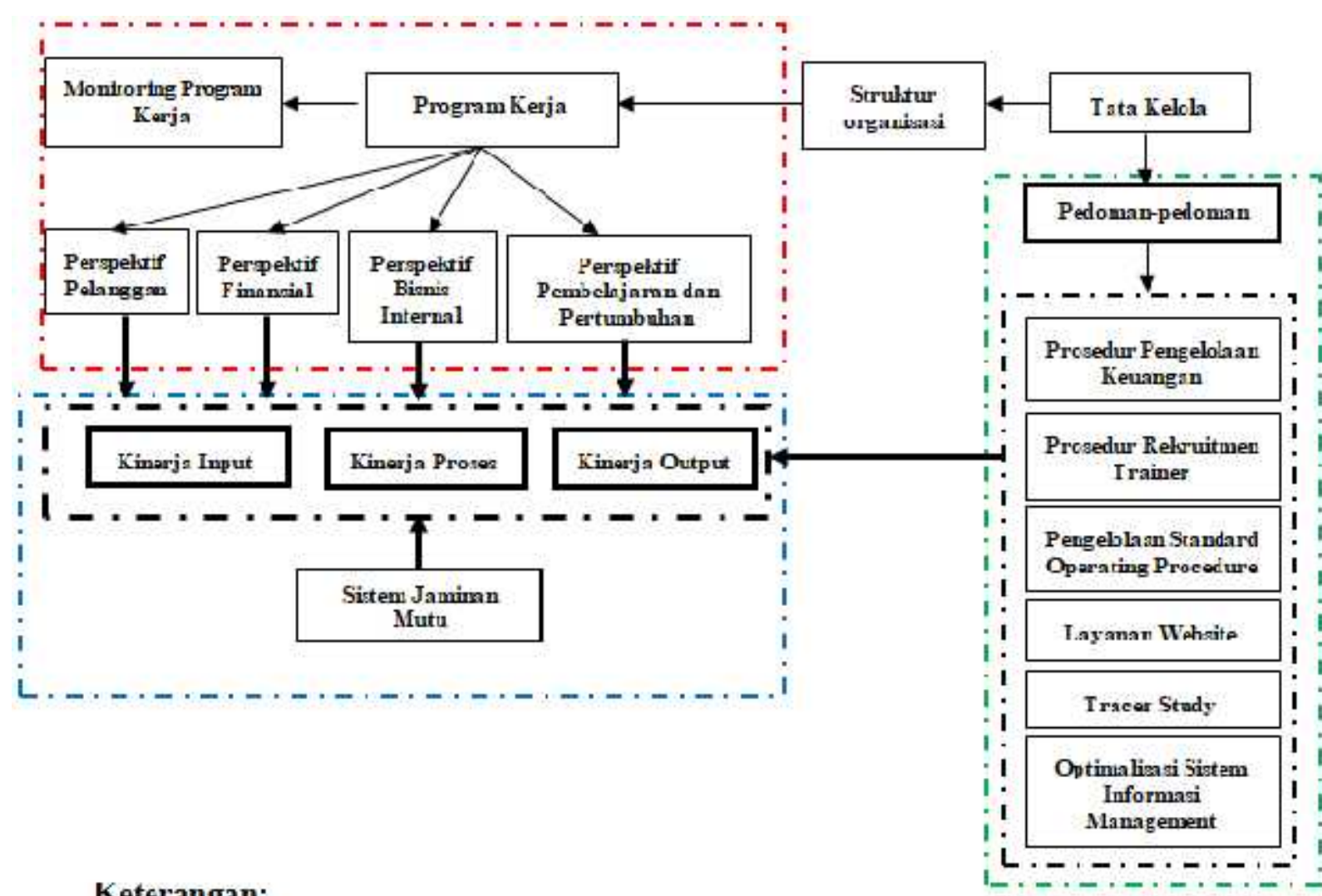

\section{Keterangan:}

$$
\begin{aligned}
& \text { Rencana Program Pengabdian Masyarakat yang dilakukan saat ini } \\
& \text { i.-. } ; \text { : Rencana Program Pengabdian Masyarakat yang dilakukan mendatang }
\end{aligned}
$$

Gambar 1.1: Roadmap Abdimas 


\section{Jurnal ABDINUS : Jurnal Pengabdian Nusantara, 3 (1), 2019, 1-10}

Bayu Cahyoadi, Andreas Andre Djatmiko

UPTD mempunyai tugas melaksanakan sebagian kegiatan teknis penunjang dinas dalam pelatihan tenaga kerja meliputi keterampilan, pengetahuan, ketatausahaan, serta pelayanan masyarakat (Bupati Tulungagung 2016). UPTD dilingkungan Disnakertrans mempunyai fungsi :

a. Penyiapan bahan perumusan program dan petunjuk teknis yang berkaitan dengan penyelenggaraan Balai Latihan Kerja;

b. Pelaksanaan kegiatan pelatihan terhadap berbagai jenis keterampilan;

c. Pelaksanaan kegiatan uji keterampilan, kompetensi, dan sertifikasi peserta pelatihan;

d. Penghimpunan data dan informasi tentang penyelenggaraan Balai Latihan Kerja;

e. Pendayagunaan dan pemberian informasi pelatihan bagi calon tenaga kerja;

f. Pelaksanaan tata usaha dan pelaporan dalam rangka penyelenggaraan latihan kerja; dan

g. Pelaksanaan tugas dinas lain yang diberikan oleh Kepala Dinas sesuai dengan tugas dan fungsinya.

Tata kelola dalam UPTD BLK Kabupaten Tulungagung dapat dijabarkan beserta susunan organisasi sebagai berikut:

a. Susunan Organisasi UPTD Balai Latihan Kerja terdiri atas:

1. Kepala UPTD.

2. Kepala Sub Bagian Tata Usaha.

3. Koordinator Pelatihan dan Sertifikasi.

4. Koordinator Pengembangan dan Pemasaran.

b. Kepala Sub Bagian Tata Usaha mempunyai tugas sebagai berikut:

1. Melaksanakan pengelolaan administrasi keuangan;

2. Melaksanakan pengelolaan administrasi perbekalan;

3. Melaksanakan pelayanan masyarakat;

4. Melaksanakan pengelolaan urusan rumah tangga, kebersihan, keamanan surat menyurat, kehumasan dan kearsipan;

5. Melaksanakan administrasi evaluasi pelatihan;

6. Membuat laporan hasil pelaksanaan kegiatan pelatihan secara berkala; dan

7. Melaksanakan tugas-tugas lain yang diberikan oleh Kepala UPTD.

c. Koordinator Pelatihan dan Sertifikasi mempunyai tugas sebagai berikut:

1. Menyusun rencana dan melaksanakan program pelatihan dan uji keterampilan;

2. Menyusun perencanaan kebutuhan perangkat keras dan lunak untuk program pelatihan dan uji keterampilan; 


\section{Jurnal ABDINUS : Jurnal Pengabdian Nusantara, 3 (1), 2019, 1-10 \\ Bayu Cahyoadi, Andreas Andre Djatmiko}

3. Menyiapkan bahan pelajaran, alat bantu pelatihan dan tenaga pengajar/instruktur pelatihan;

4. Melaksanakan administrasi pelatihan, yang berhubungan dengan persiapan penyelenggaraan pelatihan uji keterampilan;

5. Melaksanakan pelatihan dan uji keterampilan;

6. Melakukan pemantauan dan evaluasi terhadap pelaksanaan kegiatan pelatihan dan uji keterampilan;

7. Membuat laporan hasil pelaksanaan kegiatan pelatihan dan uji keterampilan secara berkala; dan

8. Melaksanakan tugas-tugas lain yang diberikan oleh Kepala UPT.

d. Koordinator Pengembangan dan Pemasaran mempunyai tugas sebagai berikut:

1. Menyusun rencana pengembangan dan pemasaran bidang pelatihan

2. Menyusun pengembangan program, sistem, metode, program, dan kebutuhan sarana dan prasarana sebagai penunjang pengembangan program kegiatan dan uji keterampilan;

3. Menyusun usulan rencana kebutuhan dan kualifikasi tenaga pengajar/instruktur pelatihan dalam rangka pengembangan program pelatihan;

4. Menjalin kerjasama dengan instansi terkait dan mempromosikan program pelatihan;

5. Mengidentifikasi rencana penempatan lulusan;

6. Menempatkan lulusan sesuai dengan rencana dan kebutuhan;

7. Memberikan layanan informasi dan konsultasi pelatihan serta layanan konsultasi uji keterampilan; dan melaksanakan tugas-tugas lain yang diberikan oleh Kepala UPT.

Berdasarkan rincian tata kelola tersebut, didapatkan fenomena dan permasalahan tata kelola yang terjadi pada UPTD BLK dan Bapenda Kabupaten Tulungagung sebagai berikut:

a. Masih belum jelasnya program kerja yang saling mendukung antar bagian

b. Masih belum jelasnya ukuran ketercapaian kinerja yang diharapkan

c. Masih belum jelasnya target kerja baik bulanan maupun tahunan

d. Masih belum adanya kejelasan model pengembangan kinerja di masa depan

e. Masih ditemui beberapa pegawai yang kurang mengerti fungsi dan tugasnya masingmasing

Dari fenomena permasalahan yang terjadi tersebut, maka UPTD BLK dan Bapenda Disnakertrans layak untuk diberikan materi dan pelatihan pembuatan program kerja yang berbasis BSC. Selain itu upaya pengabdian masyarakat ini merupakan partisipasi aktif STKIP PGRI Tulungagung dalam rangka menjalin kerjasama yang bersimbiosis mutualisme, dimana 


\section{Jurnal ABDINUS : Jurnal Pengabdian Nusantara, 3 (1), 2019, 1-10}

Bayu Cahyoadi, Andreas Andre Djatmiko

(khususnya) UPTD BLK Disnakertrans merupakan UPTD yang bergerak dalam bidang pendidikan dan pelatihan; yang sedikit-banyak mempunyai model yang relevan institusi pendidikan lain seperti perguruan tinggi.

\section{SOLUSI DAN TARGET}

Adapun tujuan dari pelaksanaan Abdimas ini adalah memberikan pendampingan dalam merumuskan program kerja tahunan dan multi tahunan di lingkungan manajemen UPTD BLKD disnakertrans Kabupaten Tulungagung dan memberikan saran dan edukasi untuk pengelolaan dalam bidang manajemen pada UPTD BLK Disnakertrans agar lebih baik mutunya pada masa yang akan datang.

Sedangkan manfaat yang dihasilkan dari program ini adalah terciptanya kerjasama yang baik antar institusi perguruan tinggi dan pemerintah, terciptanya pengelolaan manajemen yang mengacu pada teori ilmiah yang relevan, terciptanya standar pengelolaan manajemen yang tinggi pada institusi pemerintah khususnya UPTD BLK dan Bapenda Disnakertrans kabupaten Tulungagung.

Adapun target pelaksanaan program ini adalah kepada para pengelola manajemen berikut elemen yang terkait; untuk kemudian dapat dikembangkan aturan dan kebijakan baru demi keberhasilan pengelolaan manajemen yang berbasis strategi.

\section{METODE PELAKSANAAN}

\section{A. Sosialisasi Modul KPI Berdasarkan BSC}

Sosialisasi KPI berbasis BSC dilakukan dengan pertemuan dan presentasi modul untuk kemudian dilakukan tanya jawab tentang berbagai permasalahan kinerja di UPTD BLK Disnakertrans Kabupaten Tulungagung.

\section{B. Identifikasi Tata Kelola Sebagai Dasar Pembuatan BSC}

BSC yang akan dibuat didasarkan pada dimension tata kelola yang telah didapatkan, untuk kemudian dibuat tabel dengan indikator-indikator program kerja/key performance indicator (KPI) yang akan dilakukan.

\section{Pelatihan Penyusunan BSC}

Penyusunan BSC pada program ini dilakukan dengan memberikan template tabel menggunakan file Ms-word (sesuai yang tertulis pada lampiran modul), untuk kemudian diisi oleh masing-masing peserta. Dari tabel yang telah dibuat tersebut, peserta diberikan kewajiban untuk mempresentasikan hasil indikator program kerja kepada audiens untuk 
direview bersama sehingga didapatkan program kerja yang mampu dijalankan dengan baik; dan sesuai dengan harapan.

Secara terperinci alur metode pelaksanaan program ini dijelaskan pada Gambar 3.1 sebagai berikut.

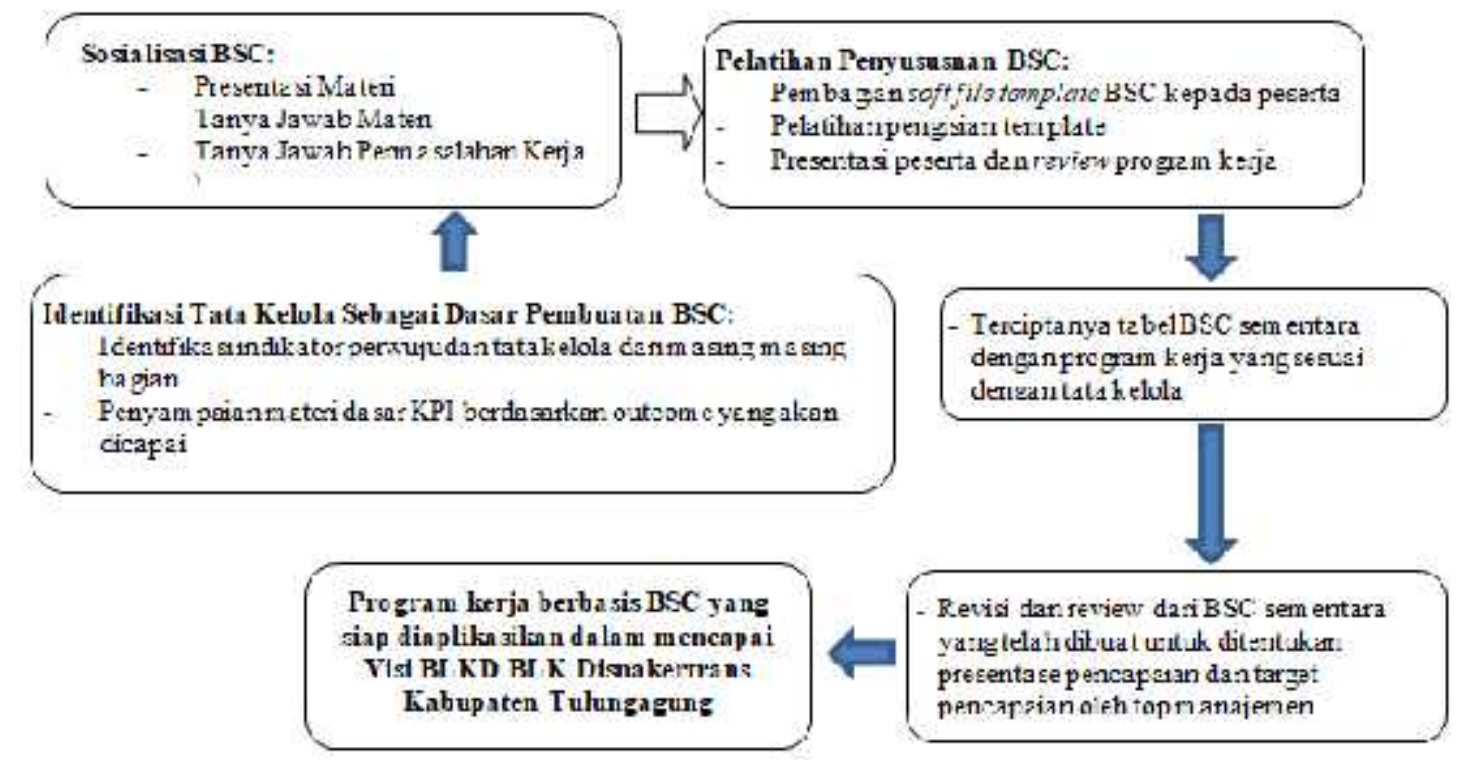

Gambar 3.1: Alur Metode Pelaksanaan Program

\section{HASIL DAN LUARAN}

Adapun hasil pendampingan pembuatan KPI berbasis Balance Score Card (BSC) disusun secara sistematis pada modul pendampingan yang terlampir pada lampiran 1 Laporan Pengabdian Masyarakat ini.

Indikator program kerja yang telah disusun merupakan serangkaian upaya pihak UPTD Balai Latihan Kerja dalam menjalankan mutu kinerja yang tinggi. KPI dibuat sedemikian rupa untuk menilai sejauh mana tingkat kemajuan tahunan yang dapat dicapai berdasarkan garisgaris target pencapaian yang didasarkan pada tujuan yang dibuat. Tujuan yang telah dibuat tersebut diharapkan dapat mendukung visi, dan kemudian diharapkan dapat menjangkau visi yang ditetapkan bersama-sama. Hasil imlementasi pelaksanaan program kerja dapat menjadi acuan bagi pihak manajemen dalam menggali informasi pencapaian kinerja semua unsur di dalam UPTD BLK Disnakertrans Kabupaten Tulungagung.

KPI yang dibuat UPTD BLK Disnakertrans sebagai UPTD yang relatif baru menggunakan indikator-indikator yang disusun perspektif pelanggan, finansial, bisnis internal, dan pembelajaran serta pertumbuhan. Semua hasil penjabaran KPI tersebut terlampir pada panduan penyusunan KPI yang terlampir pada laporan ini. 


\section{Jurnal ABDINUS : Jurnal Pengabdian Nusantara, 3 (1), 2019, 1-10}

Bayu Cahyoadi, Andreas Andre Djatmiko

Hasil KPI yang disusun, dapat dimodifikasi sedemikian rupa oleh pihak UPTD BLK menyesuaikan dengan perkembangan kondisi manajemen dan isu strategis yang mungkin akan dihadapi di kemudiaan hari; sehingga diperlukan revisi antar pihak internal UPTD BLK Disnakertrans untuk menyempurnakan program kerja yang telah dibuat sedemikian rupa.

Adapun luaran program pengabdian masyarakat ini adalah sebagai berikut.

a. Terdapat artikel jurnal hasil pengabdian masyarakat; dengan indikator draft artikel jurnal publikasi.

b. Publikasi di jurnal ilmiah nasional dengan indikator status artikel setidaknya terkirim (submitted).

c. Modul pendampingan pembuatan KPI dengan indikator terdapat draft program kerja tahunan.

\section{RENCANA TINDAK LANJUT}

Adapun rencana tindak lanjut yang akan dilakukan adalah sebagai berikut:

1. Melakukan revisi bersama dan berkelanjutan tentang KPI yang telah dibuat.

2. Mengadakan sosialisasi KPI yang telah dibuat dilingkungan UPTD lain di wilayah Disnakertrans Kabupaten Tulungagung.

3. Mengadakan pelatihan pembuatan Tata Kelola UPTD BLK Disnakertrans sebagai tolak ukur utama proses pelaksanaan kerja.

\section{SIMPULAN}

Adapun simpulan yang dapat dibuat dari pelakanaan pengabdian masyarakat ini adalah sebagai berikut.

1. Pembuatan program kerja tahunan dan multi tahunan diharapkan dapat mempermudah manajemen UPTD BLK Disnakertrans Kabupaten Tulungagung dalam merencanakan, mengkoordinasikan, mengaktulisasikan dan mengawasi pengelolaan manajemen di dalam instansinya.

2. Perencanaan program kerja tahunan dan multi tahunan tersebut sekaligus dapat menjadi acuan bagi pihak manajemen dalam menggali informasi tentang peningkatan kinerja pada UPTD BLK Disnakertrans Kabupaten Tulungagung.

3. Indikator-indikator yang digunakan untuk menyusun KPI didapatkan dari dimensi perspektif pelanggan, perspektif finansial, perspektif bisnis internal, perspektif pembelajaran dan pertumbuhan 


\section{Jurnal ABDINUS : Jurnal Pengabdian Nusantara, 3 (1), 2019, 1-10 \\ Bayu Cahyoadi, Andreas Andre Djatmiko}

\section{SARAN}

Sedangkan saran untuk UPTD BLK Disnakertrans Kabupaten Tulungagung terkait dengan pelaksanaan program meliputi berbagai hal sebagai berikut.

1. Secara berkesinambungan menaikkan mutu pengelolaan manajemen berdasarkan acuan yang dibuat, sehingga kedepannya tercipta pengelolaan UPTD BLK Disnakertrans Kabupaten Tulungagung yang berkinerja tinggi.

2. Menyelenggarakan sistem audit internal secara berkala dari pelaksanaan program kerja yang telah dibuat

3. Membuat tata kelola kinerja sebagai standar operasional dalam bekerja; baik dalam bentuk Standar Operating Procedure (SOP) maupun dalam bentuk prosedur pedoman yang lain.

\section{DAFTAR RUJUKAN}

Ahmadi, Parviz, Soheila Khoddami, Bahereh Osanlou, and Hamid Moradi. 2012. "Using the Balanced Score Card to Design Organizational Comprehensive Performance Evaluation Model." African Journal of Business Management 6(6): 2267-77. http://www.academicjournals.org/ajbm/abstracts/abstracts/abstracts2012/15Feb/Ahmadi et al.htm.

Bupati Tulungagung. 2016. "Peraturan Bupati Tulungagung Nomor 78 Tahun 2016 Tentang Pembentukan Unit Pelaksana Teknis Dinas Dan Badan Di Lingkup Pemerintah Kabupaten Tulungagung." : 1-31.

Schobel, Kurt. 2012. "Balanced Scorecards in Education: Focusing on Financial Strategies." Measuring Business Excellence 16(3): 17-28.

Umayal Karpagam, P L, and L Suganthi. 2012. “A Strategy Map of Balanced Scorecard in Academic Institutions for Performance Improvement." IUP Journal of Business Strategy 9(3): 7-16. 